\title{
Freedom of Religion in the Workplace and the Court of Justice of the European Union: A Return to the Principle of Cuius Regio, Eius Religio?
}

\section{Filip Dorssemont}

\section{(2) OpenEdition \\ 1 Journals}

Electronic version

URL: https://journals.openedition.org/rdctss/2354

DOI: $10.4000 /$ rdctss.2354

ISSN: 2262-9815

Publisher

Centre de droit comparé du travail et de la sécurité sociale

\section{Printed version}

Date of publication: 1 December 2017

Number of pages: $200-213$

ISSN: $2117-4350$

\section{Electronic reference}

Filip Dorssemont, "Freedom of Religion in the Workplace and the Court of Justice of the European Union: A Return to the Principle of Cuius Regio, Eius Religio?", Revue de droit comparé du travail et de la sécurité sociale [Online], 4 | 2017, Online since 01 November 2021, connection on 04 December 2021. URL: http://journals.openedition.org/rdctss/2354 ; DOI: https://doi.org/10.4000/rdctss.2354

\section{(c) () $\$$}

Revue de droit comparé du travail et de la sécurité sociale est mise à disposition selon les termes de la Licence Creative Commons Attribution - Pas d'Utilisation Commerciale - Pas de Modification 4.0 International. 


\title{
FILIP DORSSEMONT
}

Professor at the Catholic University of Leuven

Professor at Saint-Louis University, Brussels

Research themes: European labour law - Law of collective labour relations - workers'

fundamental rights

Publications:

- «Les religieux et la relation du travail: beaucoup de subordinations, mais peu de

contrats?», in S. Gilson, Subordination et parasubordination, Limal, Anthemis, 2017, 355-376.

- "The Right to Bargain Collectively. A Matrix for Industrial Relations", in N. Bruun, K.

Lörcher, I. Schömann and S. Clauwaert, Oxford, Hart Publishers, 2017, 249-288.

\section{FREEDOM OF RELIGION IN THE WORKPLACE \\ AND THE COURT OF JUSTICE OF THE EUROPEAN UNION:}

\author{
A RETURN TO THE PRINCIPLE OF CUIUS REGIO, EIUS RELIGIO?*
}

\section{RÉSUMÉ}

La contribution tend à soumettre deux arrêts de principe de la Cour de Justice (14 mars 2017) de I'Union européenne relatifs à la discrimination basée sur la religion ou la conviction à une analyse critique. L'auteur estime que la Cour de Justice a refusé erronément de reconnaître la nature directe de la discrimination dans l'affaire belge. II marque son désaccord quant à l'idée qu'une politique de neutralité puisse constituer un élément permettant de justifier la discrimination indirecte qui pourrait résulter d'une interdiction de porter le foulard. La référence à la liberté d'entreprendre est inappropriée et ne peut pas militer en faveur de l'interprétation restrictive d'une directive qui tend à protéger une idée de citoyenneté. La contribution contient aussi une admonestation contre la référence aux aménagements raisonnables. Elle se marie difficilement avec l'approche adoptée par la Cour européenne des droits de l'homme et elle peut confiner à une forme de harcèlement contre des travailleurs relégués « en back office».

MotS-CLÉs : Discrimination basée sur les convictions religieuses ou philosophiques, liberté de religion, port du foulard, directive UE 2000/78.

\begin{abstract}
This contribution provides a critical analysis of two landmark judgments of the Court of Justice of the European Union related to discrimination based upon religion or belief (14 March 2017). The author contends that the Court of Justice has erroneously qualified the discrimination concerned in the Belgian case as indirect discrimination. Furthermore, he argues that a policy of neutrality cannot be considered as legitimation of the indirect discrimination stemming from the prohibition of the headscarf. The reference to the freedom to conduct a business is no grounds to justify a restrictive interpretation of a directive related to the idea of citizenship. Last but not least, the author argues that the use the CJEU has made of the notion of reasonable accommodation is at odds with the approach the European Court of Human rights and contains a risk of harassment of workers confined to a space in the back office.
\end{abstract}

KEYWORDS: Discrimination on the Grounds of Religion or Belief, Freedom of Religion, Headscarf, EU Directive 2000/78.

This contribution contains the main part of the analysis in a longer, more detailed contribution originally written in Dutch submitted to The Hague, Boomjuridsch). It is the fruit of a research and teaching secondment to the Comptrasec in March and April 2017 in my capacity as a visiting professor. The provisional results of this study were the subject of an in-house seminar at the Comptrasec organised with my colleague Rachid Fillali. 
n 14 March 2017, the Court of Justice gave preliminary rulings on two questions referred respectively by the French and Belgian Courts of Cassation. ${ }^{1}$ These two judgments deserve to be considered as "landmark rulings". In fact, this is the first time that the Court of Justice has been asked to rule on the scope of the prohibition of discrimination on the grounds of "religion or belief" within the meaning of EU Directive 2000/78. This theme is illustrated in the two rulings by the different situations that (the wearing of) a headscarf can give rise to. In the question submitted for a preliminary ruling in the Belgian case, the distinction between direct and indirect discrimination is central. In the question submitted for a preliminary ruling in the French case, the French Court is asking for clarification on the concept of genuine and determining occupational requirement, which justifies direct discrimination. The Court did not fail, on this occasion, to clarify various aspects of the notion of discrimination on the grounds of "religion or belief". The referring judges were also given answers to some questions they did not want or did not dare to ask. In order to remain faithful to the spirit of a commentary on a judgment, I will limit myself to the more thorny issues that the Court of Justice thought it needed to clarify. These sensitive points form the basis of this contribution and will be set out in a logical order. The grounds for discrimination in question (religion or belief) will first of all be defined, as will the notion of direct discrimination (I) and the concept of "genuine and determining occupational requirements" which justifies direct discrimination. After that, we will analyse in more depth the introduction of a policy of neutrality, which may, in the Court's eyes, constitute a justification for indirect discrimination (II). The Court bases this policy of neutrality on the freedom to conduct a business. This basis is far from evident. In the judgment in the Belgian case, the Court alternates the expressions "internal rules" and "policy" to refer to the principle of neutrality. This wavering between the two terms is problematic. In the context of the proportionality of this policy of neutrality, the Court strikes a blow in favour of the establishment of an obligation of reasonable accommodation. This is an interesting innovation, which I will analyse (III). To conclude, the two judgments will be assessed.

\section{DEFINITION OF CONCEPTS}

\section{A - RELIGION, BELIEFS AND FREEDOM OF EXPRESSION}

The expression "religion or belief" as used in EU Directive 2000/78 is manifestly an unfortunate choice of term. It suggests a contradiction that does not exist. "Religion" as grounds for discrimination clearly also covers belief. If given a closer look, this terminology seems to have been borrowed from Article 9 §2 ECHR which guarantees the right "to

1 CJEU, 14 March 2017, C-188/15 (Asma Bougnaoui, Association de défense des droits de I'homme (ADDH) v. Micropole SA) (Micropole) and CJEU, 14 March 2017, C-157/15 (Samira Achbita, Centrum voor gelijkheid van kansen en en voor racismenbestrijding v. G4S Secure Solutions NV) (G4S Secure Solutions). 
manifest one's religion or beliefs". The German version of the Directive seems to be the clearest. It states more precisely the nature that the beliefs in question can take on by mentioning "Religion oder der Weltanschauung". The grounds covered mainly concern religious and metaphysical beliefs. On the other hand, it seems to me that the Directive does not protect political or trade union beliefs. ${ }^{2}$

The scope of the concept of "religion" is not central in the two cases. What was more relevant was whether the ground for discrimination covers only inner or intimate beliefs or if it also covers the expression of such a belief. In my opinion, the Court of Justice chooses, fortunately, to transplant the wording of Article $9 \mathrm{ECHR}$ to determine the scope of the concept of "religion or belief". This article recognises freedom of religion in absolute terms whilst it only recognises the freedom to manifest one's (religious) beliefs in relative terms.

Inevitably the question arises to which extent this exteriorisation must be related to a "religion" to be able to be qualified as a manifestation of a religious belief. In Eweida v. UK, the European Court of Human Rights held that such a manifestation does not only consist of forms of worship or devotion that are part of routine practice. A manifestation must also not be compulsory ("there is no requirement on the applicant to establish that he or she acted in fulfilment of a duty mandated by the religion in question"). More positively, the Court declares that there must be a "sufficiently close and direct nexus between the act and the underlying belief." 3 The Court thus leaves the door open to the recognition of a more personal or, might I say individual experience of religious belief which may depart from collective ritual.

The question of whether Muslim women are obliged to wear a headscarf and whether or not such an obligation is written in the Koran is not relevant in this regard and is certainly not decisive. The approach favoured by Strasbourg is a relative one and leads to a good many signs and practices being considered as manifestations of religion. In the judgment relating to the Belgian case, the signs of belief play a central role. However, practices may also be considered as manifestations. In the Eweida judgment, an omission (the non-performance of work) was even considered as a religious belief. The scope of the prohibition on discrimination was thus widened.

A certain degree of individualisation seems to be inherent in the prohibition on discrimination which, primarily, aims to protect an individual, but in no way aims to protect a religious community.

The more practices fall within the scope of the freedom of religious expression, the more they threaten to enter into the scope of the principle of "neutrality". Conversely, insofar as given practices or signs are requalified as simply cultural or ethnic phenomena,

2 This assertion seems somewhat rash. Neither the Directive nor the Court have defined the concepts of «religion» and «belief» (L. Vickers, Religious Freedom, Religious Discrimination and the Workplace, Oxford, Hart Publishing, 2016, 138). In Belgium the Constitutional Court ruled in two successive judgments that the list of grounds for discrimination in the transposition legislation should be completed with "political beliefs» ("convictions politiques») and "trade union beliefs» ("convictions syndicales») with a view to preventing discrimination among the victims of discrimination. Hence, these grounds were not covered by the grounds «religion and belief». Constitutional Court, no. 157/2004, 6 October 2004 and no. 64/2009, 2 April 2009.

$3 \S 82$ of the Eweida and Others v. the United Kingdom judgment, Applications nos. 48420/10, 59842/10, 51671/10 and 36516/10, 15 January 2013. 


\section{COMMENTS}

(the more) they escape from the scope of the policy of neutrality. The future will tell us if such an alternative approach turns out to be to workers' advantage. It could be suggested that the worker can also call on the right to freedom of expression, a more generic term, as used in Article 10 of the ECHR. However, it seems problematic to us that the legal system of the European Union has not attached to it any prohibition on discrimination.

\section{B - DIRECT DISCRIMINATION}

In the Belgian case, which gave rise to one of the two judgments of the Court of Justice, the question arises of whether a company can put an end, under the labour regulations, to the manifestation of religious or ideological beliefs in the workplace. Reformulated in more concrete terms, the question would take this form: does such a practice constitute direct or indirect discrimination? The point of view of AG Kokott (ergo: the denial of direct discrimination) was recently echoed in a reference work by an author who is a recognised authority. ${ }^{4}$ Insofar as this author could not yet have been aware of the opinion of AG Sharpston and that she takes her authority only from AG Kokott, it seems to us that there remains plenty of room for discussion. And yet it is also not because the Luxembourg Court has now issued a ruling that one should conclude to a Roma locuta, causa finita est.

The Court of Justice judged in the Belgian case that internal rules banning all religious signs are not directly discriminatory. For it to be a matter of either direct or indirect discrimination, it must be possible to identify a reference person who is or would be treated better than the victim of the discrimination. ${ }^{5} \mathrm{It}$ is also required that the difference in treatment be based on a prohibited ground for discrimination. As far as this last element is concerned, the Court could not (decently) rule otherwise than that it was the religious ground that was involved in both cases. Moreover, what is forbidden is not any headscarf worn by chance or a banal piece of fabric with no meaning at all. The ban is explicitly aimed at the external signs of religious belief. The Court nevertheless manages to go round in circles: it claims that there is no direct discrimination for, in substance, all the workers were treated equally in the light of the general "neutrality" decreed in the company.

There could therefore not be any third party who had been treated better than or differently to Ms Achbita. Obviously, the Court also takes account of the general nature of the policy of neutrality which concerns philosophical, political as well as religious beliefs. The impression given by the Court that everyone is treated is the same way really seems simplistic to us. It could just have easily been said that the rule (in question) makes a distinction between people with religious, metaphysical or political beliefs and those who have none. Just as it could also be asserted that this rule creates a distinction between workers who feel a need to express their beliefs and those who do not feel that need. As has already been rightly pointed out by Sharpston, workers who express themselves are definitely discriminated against compared to those who do not express themselves. The former are dismissed, while the latter keep their jobs. By saying this, our intention is certainly not to show that workers who choose not to express their religious beliefs do not deserve any protection. Indeed, freedom of expression also includes the freedom not to manifest one's beliefs. Nor do I wish to show that an agnostic or an atheist does not need

4 L. Vickers, Religious Freedom, Religious Discrimination and the Workplace, Oxford, Hart Publishing, $2016,140$.

5 See the definitions of direct and indirect discrimination in Article 2 2) of EU Directive 2000/78. 
protection. On the contrary: these beliefs also fall within the scope of the "belief" ground for discrimination (very accurately translated into German as Weltanschauung).

From this perspective, there is, without any doubt, direct discrimination. The Nederlandse College voor de Mensenrechten took a very clear view in this respect in its decision 2015/145:

\begin{abstract}
"The College is of the opinion that the defendant created, in this way, a direct distinction with regard to the plaintiff on the basis of religion by rejecting his application. (...) Nevertheless, the defendant's rule, which admittedly applies to all the staff, implies that applicants wishing to express their religion by wearing a particular garment, will not be hired for that reason. This means that the defendant does not treat everyone equally, as it claims to do. Sharpston, moreover, refers to this decision in her opinion, which relies heavily on comparative law. ${ }^{6}$
\end{abstract}

The willingness to look for and find a reference person is clearly a decisive step. In a previous case, the Court had to look at the dismissal by a municipality of a (transgender) administrative officer who had undergone sex reassignment surgery. ${ }^{7}$ The person in question claimed to have suffered discrimination on the basis of sex. The municipality argued that this was not the case as all workers, regardless of their sex (male or female), would have been dismissed in such an eventuality. The Court, consciously, did not go along with this reasoning. It did not compare the workers who had undergone sex reassignment surgery with each other, but undertook a comparison between those who had undergone such a procedure and those who had not. Only the former were dismissed. When the Court is ready and willing, it is therefore perfectly able to find a (an adequate) reference person.

The Court also takes account of the general nature of the policy of neutrality, which concerns philosophical, political as well as religious beliefs. ${ }^{8}$ This argument is, it seems to me, problematic. It is not because a direct discrimination on the basis of religious belief is extended to a direct discrimination for reasons of political or philosophical belief that all is well.

\title{
II - DIRECT/INDIRECT DISCRIMINATION: THE POSSIBLE JUSTIFICATIONS
}

\section{A - DIRECT DISCRIMINATION AND GENUINE AND DETERMINING OCCUPATIONAL REQUIREMENTS}

In the Micropole case, the scope of the genuine and determining occupational requirement turns ou0ember States to introduce genuine and determining occupational requirements into their legal systems, so that an interpretation in line with the Directive does not seem to be a requirement.

\footnotetext{
See Note 34 in the Sharpston opinion.

CJEU, 30 April 1996, C-13/94 (P v. S. Cornwall).

8 See consideration 41 of the G4S Secure Solutions judgment.
} 


\section{COMMENTS}

\section{B - INDIRECT DISCRIMINATION AND POLICY OF NEUTRALITY IN COMPANIES}

The Court of Justice analyses the provision in the Belgian workplace regulations as transposing the "employer's willingness to project an image of political, philosophical and religious neutrality towards its customers". ${ }^{9}$ The term "neutrality", however, does not appear in the provision of said labour regulations, which leads me to wonder exactly what the Court meant by it. Nor is there any mention of neutrality in the Directive. It is certain that the Court considers that the potential indirect discrimination that results from the application of such a provision can be a justified. ${ }^{10}$

According to the provision in the workplace regulations, it was "forbidden for workers to wear any visible signs of their political, philosophical or religious beliefs in the workplace and on engaging in any observance of those beliefs".

For the Court of Justice, neutrality is linked to "the desire to display, in relations with both public and private sector customers, a policy of political, philosophical or religious neutrality". The beneficiary of this desire is not explicitly identified, but can only concern the company.

Fundamentally, moreover, it is the company that maintains relations with the customers. The Court considers this objective as acceptable. In this respect, two arguments are put forward. The first concerns the freedom to conduct a business. The Court explains, however, that this argument supposes that this policy of neutrality only concerns workers who are required to come into contact with the employer's customers. ${ }^{11}$

The second argument is taken from the Eweida v. UK judgment. ${ }^{12}$ In this judgment, the concept of neutrality is not mentioned, but the European Court of Human Rights nonetheless recognised that "the employer's wish to project a certain corporate image" was legitimate.

\section{How convincing are these arguments?}

The reference to the freedom to conduct a business does not go without saying for all practitioners of labour law. The reference in the Charter of Fundamental Rights of the European Union has an exceptional character. This exception is not anchored in common constitutional traditions, although the freedom to conduct a business does appear in the Italian constitution as an anti-fascist reaction to economic interventionism. Nor has the freedom to conduct a business been taken from the international instruments on human rights from which the Charter draws its inspiration. In the case law of the Court of Justice, this freedom is not mobilised against the public authorities as architects of public economic law, but rather against national and European law, and that being the case, against workers. ${ }^{13}$

9 G4S Secure Solutions, § 39.

10 G4S Secure Solutions, § 39.

11 G4 S Secure Solutions $\S 38$ (In the original version in Dutch, this reads «met name», which has been translated by «notably». «Met name» implies a restrictive condition, which «notably» means «more particularly» and does not have an exclusive scope.

12 G4S Secure Solutions, § 39.

13 Cf. CJEU Parkwood (CJUE, 18 July 2013, Case C426/11) and Aget Iraklis (CJUE. 21 December 2016, Case C-201/15). 
By this intrusion of the freedom to conduct a business, the appreciation of the justification of indirect discrimination inevitably becomes a very subjective question, and even one specific to employers.

In the explanatory statement to the Charter, it is made clear that the Convention drew its inspiration from the case law of the Court of Justice. This argument is therefore rather selfreferential. According to the wording of Article 16, it seems that this right does not have much weight. It is only recognised insofar as it is exercised in accordance with EU law and national laws and practices. Consequently, this fundamental law presents all the characteristics of a "principle" within the meaning of Article 52 of the Charter. The justiciability of the principles is, in essence, limited. That said, it is, moreover, not established that the boundaries of this justiciability have been crossed in this case.

However, the Court confers on the freedom to conduct a business a reversed scope that goes against its formulation. It considers that a Directive adopted unanimously must be interpreted in accordance with the freedom to conduct a business. It uses the freedom to conduct a business to justify certain forms of indirect discriminations, which without this reference could not be justified.

Under a Directive on labour law, the Cour limits the application of the concept of neutrality to employees who are in contact with customers. By taking this stance, the Court is in actual fact incorporating a business concept of a commercial nature that is remote from labour law. It is not the company as a work community that is in the centre of the picture. The company is not examined from the inside, but in its relations with the outside world. This approach is nevertheless in line with the very foundation of neutrality, i.e. the freedom to conduct a business. However, the question of why neutrality must be limited to relations exclusively external to the company remains unexplained. Can workers not draw any rights from the image of neutrality that the company forges for itself? Or must this neutrality only serve the employer's interests? Once a company rallies to the new religion of neutrality, the question then arises as to whether the workers can avail themselves of this neutrality to protect themselves against proselytism.

The Court is in no way clearer on whether such a prohibition would be appropriate to guarantee the correct application of a policy of neutrality. This appropriateness is postulated quite plainly. ${ }^{14}$ Could anyone in all sincerity presume that Ms Achbita, who works as a receptionist in contact with customers, would only help workers or customers of the company who shared her beliefs? Can the slightest doubt remain regarding the fact that the wearing of a headscarf or cross by a colleague is in no way an act of proselytism? In Ebrahimian v. France (26 November 2015), the Court of Human Rights again justified a ban on the wearing of the headscarf in a public hospital considering that the lady in question had to treat vulnerable patients, who could easily feel intimidated. Should we treat all the customers of private companies like psychiatric patients then? 


\section{COMMENTS}

The principle of neutrality cannot, in our opinion, be confused with that of secularism.

The principle of secularism ("laïcité") has been written into the French Constitution. France is therefore a secular State ("Etat laïc"). Article 1 stipulates that: "France shall be an indivisible, secular, democratic and social Republic". From this principle, an obligation of neutrality has been deduced, which applies to the staff of public institutions. This obligation obviously requires that members of the staff of public services do not display any external signs of their religious beliefs ${ }^{15}$. The Social and Labour matters Chamber (chambre social) of the French Court of Cassation asserted in its Baby Loup judgment that a private company may not invoke this principle of secularism. ${ }^{16}$ The principle of secularism thus forms the basis of a law that organises the separation of Church and State. ${ }^{17}$

No principle of secularism exists in Belgian law. The Belgian State is described in the Constitution only as a Federal State and not as a Secular State. Contrary to the situation in France, a different conception of freedom of religion has been adopted. Constitutional religious freedom does not go hand in hand, as it does in France, with a law establishing the separation of Church and State. There is no such separation and, on the contrary, the Belgian State recognises and subsidises religions (Article 181 of the Constitution). According to such an approach, banning the wearing of the headscarf in the public sector is far from a foregone conclusion.

In a landmark decision of the President of the Brussels Labour Court dated 16 November 2015, the distinction between an inclusive conception and an exclusive conception of neutrality in the public sector was highlighted. The inclusive conception aims only to guarantee that all citizens and users of the public services are treated on an equal footing. As for the exclusive conception, it aimed to protect users of the public service from the fear (i.e. the phobia) of being treated unequally due to their religious beliefs, whether or not that fear is justified.

The President of the Brussels Labour Court judged that such an exclusive form of neutrality (which comes very close to the French vision of secularism) was unfounded in Belgian law. He allowed a petition by a certain number of female workers to declare null and void a provision of workplace regulations that banned the wearing of external signs displaying religious, political or philosophical preferences in their clothing or behaviour. The workers in question complied with the rules pendante lite, but were demanding that the provision be declared null and void due to its discriminatory nature. The President of the Court responded favourably to their petition. This decision reflects well the definition he gives of neutrality. As the President of the Labour Court rightly remarks, a federated entity such as the Brussels Rehion, which as a legislator, expressly uses the word "diversity" cannot at the same time, as an employer, dismiss diversity via such a regulation.

15 Ph. Auvergnon, «L'expression des convictions religieuses au travail en France. Une distinction des espaces du permis et de l'interdit», Revue de droit comparé du travail et de la Sécurité sociale, 2016/2, 47-49.

16 French Court of Cassation (Social and Labour Matters Chamber), 13 March 2013, no. 11. 28. 845.

17 Law of 9 December 1905 on the Separation of the Churches and the State. 
The Court of Justice of the European Union's reference to the Eweida v. UK judgment is surprising. According to this judgment, it appears on the contrary that only little weight can be accorded to a company's corporate image when it is balanced against religious freedom ${ }^{18}$. It is also hard to see how this concern for neutrality, as a component of the corporate image, could lead to a sufficient justification of discrimination based on religious grounds. In fact the European Court of Human Rights requires that the employer be able to prove that the wearing of religious symbols has a negative impact on the company's image. ${ }^{19}$

One could see in the criticism relating to the inconsistent application of this ban by British Airways, for which turbans and hijabs did not pose any problem, a foretaste of the requirement for consistency and systematicity laid down by the Court of Justice.

In the request for a preliminary ruling made by the Belgian Court of Cassation, it was supposed that there was an internal rule within a private company that consisted of a "general ban on visibly wearing political, philosophical or religious signs in the workplace". The issue was therefore whether such a rule involved direct discrimination.

The Court's response was that it did not. The Court did not express an opinion on whether or not this internal rule actually existed in the first place. In this case, however, the question does arise of whether such an internal rule really exists. The workplace regulations were only altered at the time of Ms Achbita's dismissal. The finding that said regulations had not yet come into force at the time of the dismissal seems to us problematic nonetheless. Under Belgian law, the adoption of workplace regulations is not a prerogative of the company's management. In companies where a works council ("Conseil d'entreprise") has been set up, the establishment of workplace regulations is a matter for the works council. In Belgium, the works council is chaired by the management: it is a "mixed body".

Inevitably the question arises as to whether the Belgian Court of Cassation could not, in spite of the Court of Justice's response, find that, for these reasons, there was no internal rule. Of course, it may obviously be claimed that there was an "unwritten" rule in the company that was only formalised after the fact by the works council. At the risk of being accused of cynicism, one could even argue that Ms Achbita's behaviour in expressly asking for permission to wear the headscarf shows that she was aware of the existence of the unwritten rule.

The law on workplace regulations indicates what items must be mentioned in them. Dress requirements are not on the list. It is stated that breaches of discipline sanctioned by fines in the regulations must be foreseeable. This law does not contain, however, any obligation to provide an exhaustive list of all the possible breaches of discipline. Only the disciplinary sanctions must be specified exhaustively.

Ms Achbita's behaviour, in any case, was not the subject of disciplinary proceedings, but dismissal proceedings. 


\section{COMMENTS}

The Court of Justice examines, as part of the evaluation of the indirect discrimination, the requirement that the indirectly discriminatory provision, measure or practice must be objectively justified by a legitimate objective and that the means to achieve this aim be appropriate and necessary. The Court deduces from this requirement for appropriateness several formal conditions. Thus, the Court supposes that "the policy is genuinely pursued in a consistent and systematic manner". ${ }^{20}$

The Court seems, for these reasons, to leave the door open to indirect discrimination as long as it is based on "internal rules" or a "policy". The only decision criterion of which there is any question is coherence and systematicity.

The absence of consistency and systematicity then raises reasonable doubts as to the appropriateness of the indirect discrimination. It could also be added that a lack of systematicity and consistency raises questions as to the credibility of the objective invoked. Yet the term credibility does not appear in this judgment. The Strasbourg Court, however, does attach some importance to credibility when the employers rely on religious freedom to place restrictions on the exercising of the fundamental rights granted by the ECHR. In the Belgian case, it is nevertheless the worker and not the employer that is relying on her religious freedom.

The Court does not seem to give priority to the need for a written rule. Positively, that means that a written rule does not suffice. The Court also seems to examine the reality of the application of and compliance with the rule. Whenever a written rule, or even any rule at all, does not seem to be required, then a simple policy would suffice.

The formula matches the terminology characterising the definition of indirect discrimination. This terminology leaves the way open to a form of indirect discrimination that is not per se of a regulatory nature, such as criteria or practices.

The question that arises, however, is whether it can be considered as acceptable that employers should be able to discriminate against workers on the basis of unwritten rules. Concerning direct discrimination, the Directive expressly points out that only the Member States are authorised to determine whether genuine and determining occupational requirement can justify discrimination. Consequently, at first sight, it could be deduced, on the contrary, that employers have the power to justify indirect discrimination in other ways.

In my opinion, a good number of arguments plead in favour of theory that indirect discrimination can only be justified by written rules. Discrimination based on religion or belief is distinct from certain other types of discrimination as a result of the undeniable and intrinsic link it has with certain fundamental freedoms or rights. It seems to us quite plausible to say that discrimination based on religion or belief often constitutes a restriction on religious freedom. Subsequently, it is by no means asserted that such restrictions on religious freedom can never be legitimised. The conditions that restrictions on fundamental rights must meet in order to be allowed, are also not the same per se as the conditions that authorised (indirect) types of discrimination must meet. Concerning indirect discriminations, a proportionality test will suffice whereas for restrictions on the fundamental rights guaranteed by the ECHR, a test of legality is required in addition: these restrictions must be prescribed by law. The test that applies to fundamental rights proves to be stricter and more rigorous. 
Concerning direct discrimination, the opposite prevails. The acceptability of direct discrimination is conditioned by a legality test and a proportionality test. This proportionality test, however, proves to be stricter than the one relating to the fundamental rights guaranteed by the EHCR. Sharpston expressly insists on this point in her opinion. ${ }^{21}$ Thus, it is underscored that direct discrimination can only be limited by genuine and determining occupational requirement, whilst the Convention leaves room for a wider possibility of legitimation.

One argument that pleads in favour of a more inter-textual interpretation of the prohibition of discrimination on the basis of religion or belief seems to be the fact that the Charter of Fundamental Rights of the European Union expressly recognises religious freedom. Furthermore, the Court of Justice expressly emphasises the importance of this fundamental right for of the interpretation of the Directive, when it analyses the scope of the concept of "religion". The Court has even admitted that Article 9 of the ECHR is a relevant framework for the interpretation of Article 10 of the Charter. This is clear from the explanatory statement of Article 10 of the Charter to which the Court refers More relevantly, it seems to us that Article 52, $\S 3$ of the Charter expressly imposes that insofar as the Charter contains rights corresponding to rights guaranteed by the European Convention for the Protection of Human Right, their meaning and their scope are the same as those conferred upon them by said Charter. For a proper understanding of the scope of the fundamental rights, an interpretation of the system of restrictions is at least as important as the definition of the concept itself.

Furthermore, Article 52, $\$ 1$ of the Charter expressly stipulates that the limitations on the exercising of the rights and freedoms recognised by the Charter must be prescribed by law.

It is therefore inexplicable that on the one hand, the Court draws its inspiration from the Charter and the Convention in order to determine of religion, while on the other hand, it casts the Convention aside when examining the justification of discrimination. The Charter is therefore only a source of inspiration when delimiting religious freedom. Here the Court draws its inspiration from the freedom to conduct a business. Hence, it leaves aside the horizontal rules relating to the limitations on the exercising of the fundamental rights and to the conflicts of those fundamental rights.

The underlying reasoning behind this requirement resides in the fact that the boundaries/limits of the fundamental rights recognised by the Convention must be foreseeable and known. The conceivable consideration that Ms Achbita in the case in point was aware of the employer's policy should not lead us to forget that this is not the case for novices. They are not aware of the policy or of the company's unwritten rules. This is why, in Belgium, workplace regulations are subject to an obligation of publicity. They are signed when an employee is hired and the employer must display them in a place accessible and visible to all where everyone can consult them.

It seems to us that this represents a legal policy in favour of choosing a set of (internal) regulations rather than a policy. Regulations are much more strictly supervised in a company than a policy is. In a certain number of countries, regulatory power has largely been taken out of the hands of the employer. 


\section{COMMENTS}

It has been entrusted to works councils. In France, the employer must consult the works council ("comité d'entreprise") and draft sets of company rules are subject to preventive checking of their legality by the labour inspectorate. Such safeguards disappear in the case of a policy.

\section{III - REASONABLE ACCOMMODATION AND PROPORTIONALITY}

The Court of Justice strikes a blow, in the Belgian case, for the introduction of a right to reasonable accommodation. In Directive $2000 / 78$, this right is only expressly guaranteed for disabled workers. A refusal to provide such reasonable accommodation is equated with unjustifiable indirect discrimination. ${ }^{22}$

In the Belgian case, the Court gives the employer an instruction: to see whether the dismissal could not have been avoided by offering the worker a job not involving contact with the public. ${ }^{23}$ It can thus be argued that the test of necessity of the indirect discrimination being an integral part of the proportionality test requires a qualified obligation of reasonable accommodation. Beyond this brilliant discovery in itself which allows for a form of generalisation of reasonable accommodation, there are, in my opinion some qualifications to be made.

First of all, it seems to us that there is a notable difference between the obligation explicitly provided for by the Directive to implement reasonable accommodation and the defence of a worker based on his/her employer's refusal to offer him/her a job that does not involve direct contact with the public. The latter consideration concerns the requirement that the justification of indirect discrimination must meet the necessity test. The Court had previously emphasised that a policy of neutrality aimed at workers who were not in contact with the public was disproportionate in itself. ${ }^{24}$ The expression "reasonable accommodation" supposes that an employer must agree to make considerable efforts with a view to avoiding any discrimination based on disability. In G4S Secure Solutions, the Court declares, however, that did not have to take on an additional burden. ${ }^{25}$ Certain practical problems can also be reported: is it possible to divide up jobs between all those that involve contact with the and those that do not? ${ }^{26}$ Are there still any such jobs?

In Eweida, British Airways proposed a solution of this kind, but it came to nothing. Mrs Eweida in fact refused this solution, in spite of the financial advantage that taking this position would have meant. The limitation of religious freedom did not pass the proportionality test. That being the case, whereas the idea of reasonable accommodation in the case of handicap refers to a duty of an employer, in Eweida the worker has a right to refuse such accommodation. A worker does not have to agree to the occupational tasks described in his/her contract being unilaterally altered. Put differently, a worker can (sometimes) refuse the offer made to him/her without jeopardising his/her job.

\footnotetext{
22 Indeed, see Article 2, paragraph 2ii) of the Framework Directive 2000/78.

23 G4S Secure Solutions, § 43.

24 G4S Secure Solutions, § 42.

25 G4 S Secure Solutions, § 43.

26 See the considerations of U. Ringelheim, «Une entreprise privée peut-elle interdire à ses salariés de porter le foulard au travail?», in http://www.justice-en-ligne.be/
} 
Furthermore, it is arguable whether a proposal by the employer leading to the worker being relatively isolated is admissible under the Directive. Indeed, the Directive prohibits "harassment". The latter is defined as " unwanted conduct related to any of the grounds referred to in Article 1 takes place with the purpose or effect of violating the dignity of a person and of creating an intimidating, hostile, degrading, humiliating or offensive environment".

Naturally, it can be argued that proving harassment is no small matter. However, harassment does not imply a need to provide proof that there was an intention to violate a person's dignity. In addition, it seem to me, rightly, that victim of harassment can rely on the rules on the burden of proof. The fact that the Directive does not specify whether harassment is a form of direct or indirect discrimination does not seem to us to be relevant. The reversal of the burden of proof applies in both cases. If a practice is discriminatory, it is (necessarily) directly or indirectly discriminatory. Tertium non datur.

Furthermore, the question will arise as to whether a unilateral modification of the job cannot be assimilated in Belgian law with an act amounting to a breach of contract. The isolation of a worker can, in certain given circumstances, be considered as a form of harassment. Now, the Directive clearly analyses harassment as a form of discrimination.

\section{CONCLUSION}

In these two judgments the Court operates a sort of Freudian sublimation. It shows little empathy for employers who openly hide behind the xenophobia or islamophobia of their customers. The attitude of these employers is proof of a certain cowardice. In the Micropole case, it even involved cowardice from a twofold perspective. Micropole was hiding behind the company that used Micropole's services and it in turn was hiding behind the phobias of its workers. Fear is a bad counsellor, especially in the field of the law on discrimination. The law on discrimination also has an educational role. It is designed to transcend such phobias. In the Belgian case, the Court truly paved the way for the sublimation of these phobias by recognising companies' right to establish so-called policies of neutrality. It is not because such a policy is applied systematically and consistently that it ceases to be problematic.

The establishment of a policy of neutrality was previously, fundamentally, a prerogative of the public authorities, which advocated a certain vision of the separation between Church and State. It would seem that companies now find themselves endowed with "sovereign powers". It is no longer the customer who reigns supreme, but the company. In fact, this constitutes a reversal of the case law of the French Court of Cassation. We had learned, as it happens, from the Baby Loup judgments that companies could not rely on the principle of neutrality or secularism, but could on the other hand rely on genuine and determining occupational requirements to establish the boundaries of the freedom of religious expression.

One apparent consequence of this precedent is that freedom of religious expression will in the end depend on the arbitrary decision of a company's management. Freedom of religious expression then ceases to be a question of the individual autonomy of a citizenworker and to become a matter dependent on the autonomy of the employer which can and must rely on its freedom to conduct a business. This observation leads to an unfortunate analogy with the timid, embryonic recognition of religious freedom in the Augsbourg peace treaty. In this Treaty, the Charles V recognised the principle of Cuius regio, eius religio. It was 


\section{COMMENTS}

no longer the Emperor, but the secular authorities of the entities making up the Holy Roman Empire who would determine the Christian denomination (Catholicism or Lutheranism) that would be obligatory for their subjects. Such an approach essentially misconstrues religious freedom, which is not the prerogative of a ruler, but that of the individual or citizen him or herself. It protects the citizen against such rulers. It is the rulers and not the citizens who must be neutral.

The approach taken by the Court is in contradiction with the structure and spirit of the Treaty on the Functioning of the European Union. While the freedom to conduct a business is certainly not without relevance to certain policies of the European Union (Part Three: Union policies and internal actions), including within the ambit of the internal market and on the edge of the Social policy, the principle of non-discrimination is developed in the second part of the TFUE (Part Two: Non-discrimination and citizenship of the Union). In cases relating to citizenship, freedom of expression is, in our opinion, a Fremdkörper (foreign body), unless it is considered that the single idea of the market should colonise all the spheres and dimensions of our life in society. We thought that totalitarian utopias had gone out of fashion.

Whereas freedom of expression has historically been delimited by the vertical relationship between companies and the public authorities, this principle is mobilised, through the fault of the Court, in a more and more horizontal way against labour law and against workers. The G4S Secure Solutions radicalises this approach by mobilising the freedom to conduct a business against citizenship of the European Union.

And last but not least, it is necessary to be prudent in the face of the risk of a spillover effect concerning the principle of neutrality. If the principle of neutrality is recognised, one is called to ensure that all beliefs (read as: the expression of those beliefs) are banned. Judging otherwise would make it possible to acknowledge that the policy of neutrality is not exercised consistently and systematically and would therefore be structurally selective and discriminatory. Concerning trade union freedom, which is not regulated by the Directive, this would lead us to the absurd conclusion that workers can sympathise with the trade union and paid members' dues, but that all forms of trade union action would be prohibited. Where does this neutrality end?

In the future will actual flesh-and-blood workers have to behave like "sexless angels", devoid of sexual orientation or identity?

In actual fact, the judgment handed down in the Belgian case suffers from a contradiction. It is contradictory, on the one hand, to claim that the prohibition of discrimination concerns both the forum internum and the forum externum, and on the other hand, to argue that this forum externum should have to be moved outside the company's doors in the name of the freedom to conduct a business. Last but not least, the scope of the "essential content" of the first paragraph of Article 52 of the Charter of Fundamental Rights of the European Union should be recalled. The compromise proposed by the Court essentially means that once they have passed the doors of the company, workers no longer have the right to feel their religious beliefs in pectore. This compromise, which thus reduces to nothing the only important and relevant component of religious freedom is therefore a compromise that affects the essential content of religious freedom. On the other hand, we cannot really see how the freedom to conduct a business would be impacted in its very substance when workers are authorised to wear a headscarf which in no way prevents the performance of the work as stipulated in the contract. 